厚膜レジストにおける実測溶解速度を用いたプロキシミティ・ リソグラフィ・シミュレーションの検討

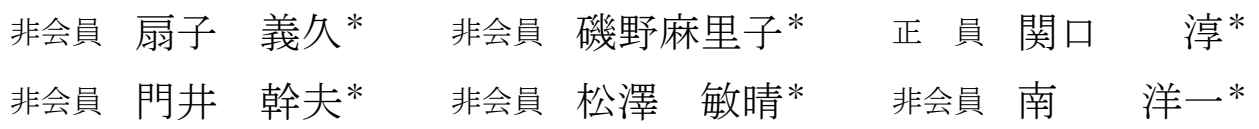

\title{
Study of Proximity Lithography Simulations Using Actual Measurements of Dissolution Rates in Thick Resist Films
}

Yoshihisa Sensu*, Non-member, Mariko Isono*, Non-member, Atsushi Sekiguchi*, Member, Mikio Kadoi*, Non-member, Toshiharu Matsuzawa*, Non-member, Youichi Minami*, Non-member

In the present paper, simulations of photoresist pattern during proximity exposure, using measured values for the dissolution rate in the photoresist, are reported. We adopted the van Cittert-Zernike theory and Hopkins equation as a model of the radiation intensity distribution in photoresist during proximity exposure, and used a film thickness measurement system to measure the film thickness of photoresist during development as a means of determining the dissolution rate. The results of simulations pattern were then compared with SEM observation results to examine the validity of this method.

As experiments to corroborate the validity of this simulation method, a diazonaphthoquinone (DNQ)-novolac positive thick-film resist (hereafter referred to as "thick film resist") was used in patterning with a broad-wavelength (350 $\mathrm{nm}$ to $450 \mathrm{~nm}$ ) mask aligner, and SEM observations were performed. In addition, simulations were conducted, and the resulting shapes were compared. Agreement was observed between the SEM observation results and the simulation results, and the differences in shapes for rough pattern dimensions and for fine pattern dimensions could be calculated. This indicates the validity of the proposed method.

キーワード : 厚膜レジスト, 溶解速度, プロキシミティ・リソグラフィ, レジスト形状シミュレーション, マスクアライナー Keywords : thick film resist, dissolution rate, proximity lithography, resist pattern simulation, mask aligner

\section{1. まえがき}

近年, 厚膜フォトレジストがマイクロマシーン /MEMS(Micro Electro Mechanical Systems)，ハードディスク， TAB(Tape Bonding), COG(Chip On Glass)のバンプ形成用, CSP(Chip Scale Package)やメッキ工程に用いられている(1)。 厚膜フォトレジストは, IC などに用いられる薄膜フォトレ ジスト用のプロセスをそのまま導入すると解像度が低下す るなどの問題が指摘されている(2)。そこで, 厚膜フォトレジ ストに最適な厚膜フォトレジスト専用のプロセスが必要で ある。それらの状況の中で, フォトレジストの形状シミュ レーション技術が重要になってきた。

フォトレジスト形状シミュレーションについては， Dill らが発表したモデル(3)（以下 Dill モデルと記述）を基本とし

\footnotetext{
リソテックジャパン(株)

干332-0034 川口市並木 2-6-6-201

Litho Tech Japan Corporation

2-6-6-201, Namiki, Kawaguchi 332-0034
}

てさまざまの高精度化手法が示されている。それらを大別 すると，フォトレジスト内の光強度分布の計算方法に関す るものと, 現像計算に関するものである。まず, 前者であ るが, Dill らの方法は, フォトレジスト表面での光強度を計 算するモデルであるのに対し, Yeung, Mack, Bernerd, Henken $^{(4) \sim(7)}$ らの方法は, フォトレジスト膜内のデフォーカ ス効果を数值計算で取り込む（Bulk Image Model）ことによ り，より現実に近いシミュレーションを可能にした方法で ある。

他方，現像計算に関しては, Grindle らが提案した実測速 度を用いる以下のような手法がある。すなわち, Dill モデル は，フォトレジスト表面上の光強度の計算に始まり，レジ ストの感光, 現像過程すべてを数值計算によってシミュレ 一トするのに対して, Grindle らは，光強度分布については， 数值計算で求めるが, 現像シミュレーションは, 溶解速度 の実測值に基づいて行う方法を提案している ${ }^{(8)}$ 。

この方法の利点は, Dill らのモデルに不可欠の感光パラメ 
一タ $A, B, C$ や現像パラメータ $E_{1}, E_{2}, E_{3}$ を必要としない

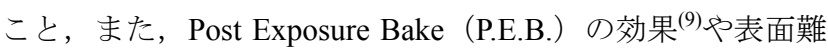
溶化効果 ${ }^{(10)}$ がすべて実測現像速度に反映されている。

我々は，フォトレジスト表面の光強度分布を用いる Dill モデルと実測溶解速度により現像シミュレーションを行う モデル（Grindle らの方法）を組合せてマスクアライナーを 用いたプロキシミティ露光のシミュレーションを行った。 これまでのところ，この手法に関する報告は無い。

本論文では，非接触型の膜厚測定装置によりフォトレジ ストの溶解速度を測定し, 我々の開発したシミュレータ ProxSim-1（PROXimity SIMulator）を用いたシミュレーショ ン結果と実測結果を比較したので報告する。本論文の構成 は以下の通りである。項目 2 から 5 で ProxSim- I の概要を 説明し, 項目 6 で実験結果及び結果の検討について述べる。 最後に項目 7 で本論文をまとめる。

\section{2. 光強度分布の計算}

〈2·1〉レジスト表面の光強度分布 図 1 にレジスト に露光される光強度分布の模式図を示す。マスク上の $\mathrm{Cr}$ パ ターンのスリットを透過した光は, $\mathrm{Cr}$ パターンにより回折 が起こる。回折した光により，レジスト表面上の光強度分 布は, 理想光強度分布に比べて劣化する。このマスク透過

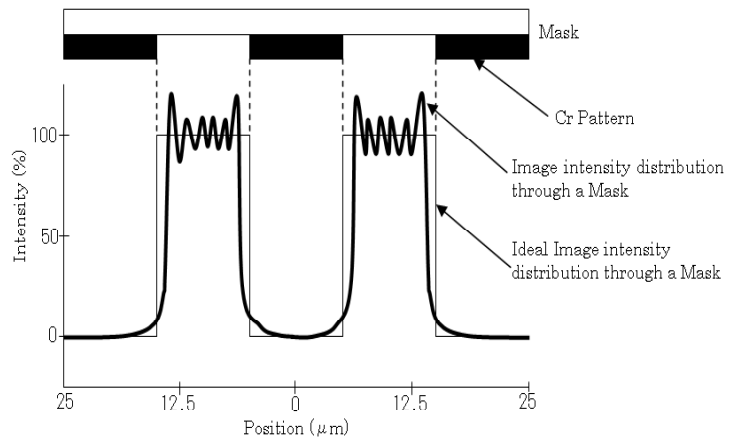

図 1 レジスト表面における光強度分布図

Fig. 1. Image intensity distribution on the resist surface.

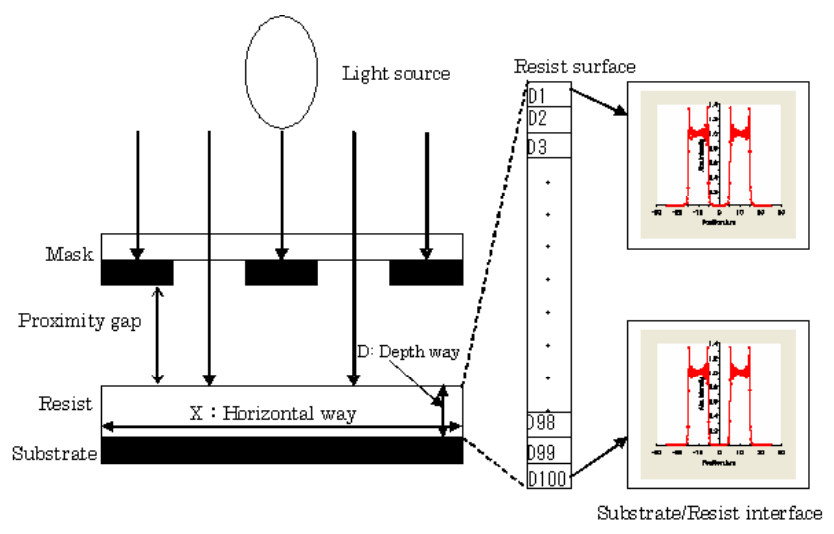

図 2 レジスト膜内の光強度分布図

Fig. 2. Schematic illustration of image intensity distribution in resist film.
後の光強度分布は van Cittert-Zernike の理論 ${ }^{(11)(12) お よ ひ ゙ ~}$ Hopkins の式より求めた ${ }^{(13)}$ 。

今, プロキシミティ露光光学系を考えた場合, レジスト 面を表す $Q$ 平面上での相対的光強度 $I(Q)$ は(1)式で求めら れる。

$$
\begin{aligned}
I(Q)= & \iint_{A} \int_{A} I(S) \frac{\exp \left[2 \pi i\left(R_{1}-R_{2}\right) / \lambda\right]}{R_{1} R_{2}} \\
& \times \frac{\exp \left[2 \pi i\left(S_{1}-S_{2}\right) / \lambda\right]}{S_{1} S_{2}} \Lambda_{1} \Lambda_{2}^{*} d S d P_{1} d P_{2}
\end{aligned}
$$

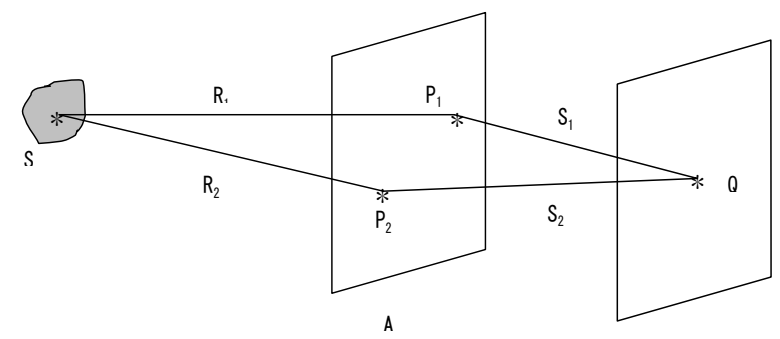

ここで, $\lambda:$ 光の波長, $S:$ 光源, $A$ : マスク面, $P_{1}, P_{2}$ : マスク面上の点, $R_{1}, R_{2}$ : 光源 $S$ から マスク面上 $A$ の点 $P 1$ と $P 2$ までの距離, $S_{1}, S_{2}$ : 点 $P_{1}$ と $P_{2}$ からフォトレジスト表面 $Q$ までの距離 を表す。

〈2·2〉レジスト内部の光強度分布 プロキシミティ 露光におけるフォトレジスト膜内の光強度分布の模式図を 図 2 に示す。まず, フォトレジスト膜 D を 100 等分し, 分 割した各層の界面に表面から基板に向って $\mathrm{D}_{1}$ から $\mathrm{D}_{100}$ の番 号を付ける。この 100 層の界面位置にフォトレジスト表面 位置における光強度の計算結果を用いる。フォトレジスト 線幅方向 X（水平方向）については, 128 に分割してフォト レジスト表面位置における光強度の計算結果を用いる。

\section{3. レジスト膜深さ方向の溶解速度分布の測定}

フォトレジストの溶解速度は図 3 に示す非接触型の膜厚 測定装置（Foothill 社製モデル KT-22t）を用いて測定した。 溶解速度測定方法のフローを図 4 に示す。まず，フォトレ ジスト塗布・プリベークを行った基板の面内に 22 種類の露 光量 $\mathrm{E}_{1}$ から $\mathrm{E}_{22}\left(0\right.$ から $\left.2000 \mathrm{~mJ} / \mathrm{cm}^{2}\right)$ を露光したサンプル を 6 枚準備する。6 枚のサンプルの現像時間は 5 分, 10 分, 15 分, 20 分, 25 分, 30 分とした。各サンプルの 22 種類の

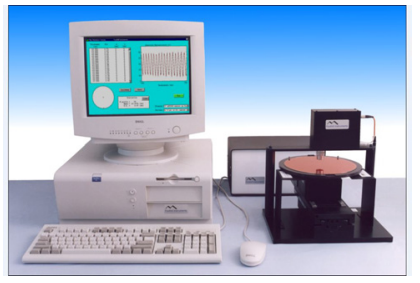

図 3 レジスト膜厚測定装置

Fig. 3. Resist thickness measurement system. 

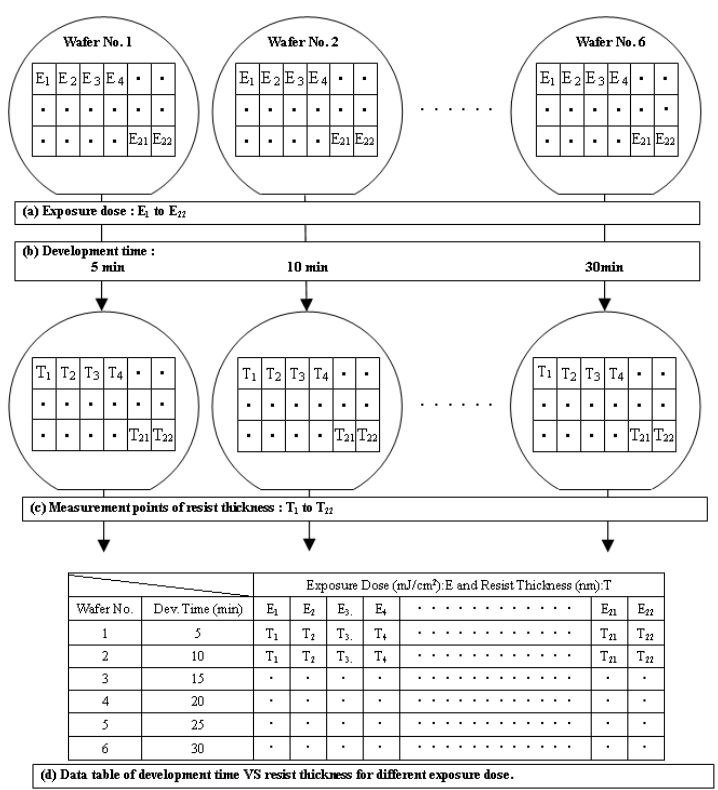

図 4 溶解速度測定方法のフロー

Fig. 4. Measurement method of development rate.

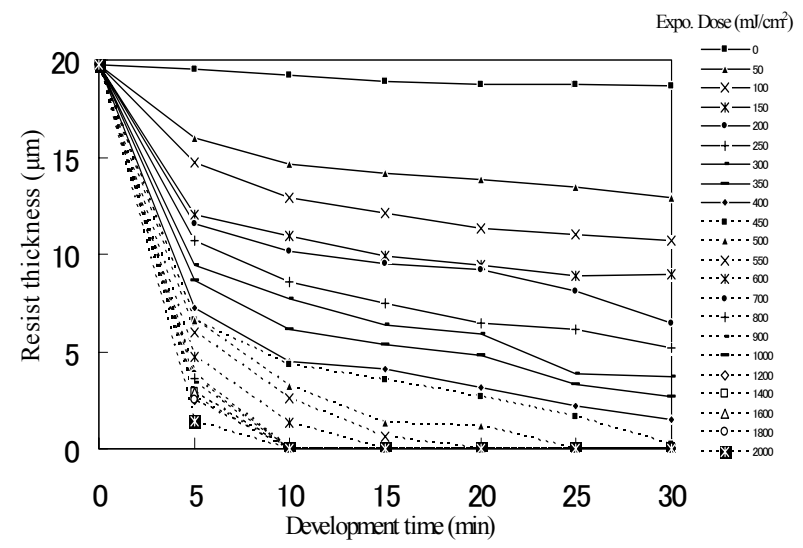

図 5 現像時間対レジスト膜厚值の測定結果

Fig. 5. Measurement result of development time vs resist thickness.

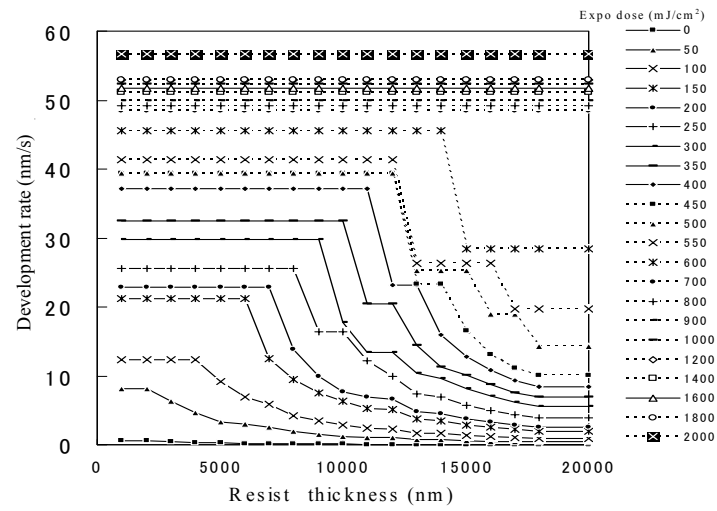

図 6 各露光量におけるレジスト膜内方向の溶解速度

Fig. 6. Development rate of in the resist film for the defferent exposure dose.
露光部の現像後のフォトレジスト残膜值 $\mathrm{T}_{1}$ から $\mathrm{T}_{22}$ を膜厚 測定装置にて測定することにより，各露光量における現像 時間対フォトレジスト膜厚值の測定を行った。得られた現 像時間対フォトレジスト膜厚值の結果を図 5 に示す。さら に，図 5 の現像時間とフォトレジスト膜厚值の関係を微分 することにより各露光量に対するフォトレジスト膜内方向 の溶解速度分布が得られる（図 6 )。

\section{4. フォトレジスト膜中溶解速度分布の計算}

フォトレジスト膜内の溶解速度分布の計算手法を図 7 に 示寸。先に示したフォトレジスト膜中光強度分布 $E\left(X_{m}, D_{n}\right)$ は, 空間上での光強度分布であり, フォトレジスト表面位 置における光強度分布の計算結果を膜中の全ての位置 $\mathrm{D}_{1}$ から $\mathrm{D}_{100}$ に用いた (図 7 (a))。今, 膜中光強度分布のフォト レジスト線幅方向の位置 $X_{m}$, 深さ $D_{n}$ における光強度 $E$ が例 えば $650 \mathrm{~mJ} / \mathrm{cm}^{2}$ であるとする。この光強度 $650 \mathrm{~mJ} / \mathrm{cm}^{2}$ は，フ オトレジストの光吸収効果を考慮していないので光学系に より決定される光強度のみを表している。次にフォトレジ ス卜膜内での光吸収効果や多重干涉効果を考慮した位置 $\left(X_{m}, D_{n}\right)$ におけるフォトレジスト溶解速度を求める必要

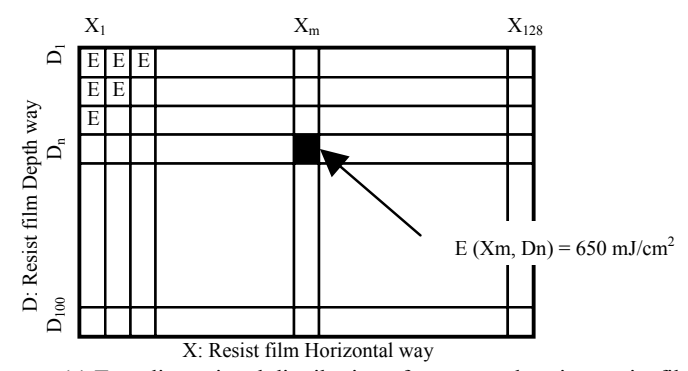

(a) Two-dimensional distribution of exposure dose in a resist film

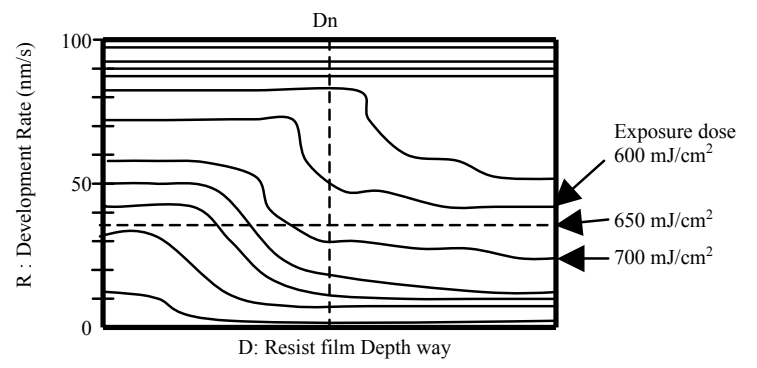

(b) Development rate distribution in a resist film

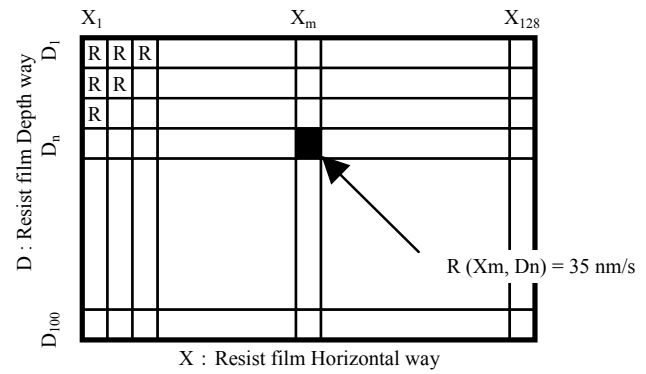

(c) Two-dimensional distribution of development rate in a resist film

図 7 レジスト膜内の溶解速度の計算手法

Fig. 7. Procedure for estimating two-dimension development rate distribution in a resist film. 
がある。なぜならば，これらの効果すべてが実測の溶解速 度分布の中に取り込まれているからである。この効果は実 測データから求められる。図 7 (b)は, 実測されたフォトレ ジスト膜中溶解速度分布である。図の右の照射エネルギー はレジスト表面における值である。フォトレジスト表面の 光強度はフォトレジストの光吸収を含まないのでこの光強 度に対応する深さ $D_{\mathrm{n}}$ におけるフォトレジスト溶解速度を求 める。図 7 (b)のように $650 \mathrm{~mJ} / \mathrm{cm}^{2}$ に直接対応するデータは 無いが， $600 \mathrm{~mJ} / \mathrm{cm}^{2}$ と $700 \mathrm{~mJ} / \mathrm{cm}^{2}$ に関するデータが存在する ので内挿により $650 \mathrm{~mJ} / \mathrm{cm}^{2}$ に対応する溶解速度 $R\left(X_{m}, D_{n}\right)$ を決定する。図 7 (c)のように以上の操作をすべてのセルに ついて行うとレジスト膜中溶解速度分布が作成できる。以 上の処理により，位置 $\left(X_{m}, D_{n}\right)$ における溶解速度が推定 できたことになる。この妥当性については，Mackらのモデ ルを表す式(2)を参照することにより明確になる。

$$
I(x, d, z)=\operatorname{Ii}\left(x, d_{0}\right) I s(z)
$$

ここで $I i\left(x, d_{0}\right)$ は，レジスト表面における光強度分布で あり, $I s(\mathrm{z})$ は, 光の多重干渉, 吸収の項である。すなわち, フォトレジストが全く存在しない場合には，レジスト表面 における光強度分布がそのままレジスト膜内においても減 衰しないので深さ $d$ における光強度分布 $I i\left(x, d_{0}\right)$ として 表されるが，実際にはフォトレジストが存在し，種々の効 果を受けるので深さ $d$ における光強度分布は, $I i\left(x, d_{0}\right)$ の ままで有り得ず $I S(z)$ の分だけ変化することになる。本論 文の手法では $R\left(X_{m}, D_{n}\right)$ がこの Is $(z)$ に相当すると考え られる。

\section{5. レベル・セット法による現像計算}

フォトレジスト膜中溶解速度分布とレベル・セット法 ${ }^{(14)}$ を用いて現像計算を行う。レベル・セット法は，原理的に は, 光学で用いられる Eikonal 方程式の解法であり, レジス 卜表面の移動について最短時間の原理を適用する。手法と してはセル・リムーバル方法 ${ }^{(15)}$ に似た計算方法である。

\section{6. 実験結果及び結果の検討}

〈6-1〉実験条件 実験条件及びサンプル作製プロセ ス・フローを図 8 に示す。フォトレジスト塗布・ベーク装 置はLITHOTRAC（リソテックジャパン社製モデル LARC-1000) を用いジアゾナフトキノン(DNQ)ノボラック系 厚膜用ポジ型フォトレジスト（以降単にフォトレジストと 記述）を $\mathrm{Si}$ 基板に $19.8 \mu \mathrm{m}$ 厚に塗布した。このときのプリ ベーク条件はプロキシミティ・ベーク方式を用い, 露光後 に発生する $\mathrm{N}_{2}$ 発泡現象によるパターン形状の劣化の少ない 条件 ${ }^{(16)}$ の $125^{\circ} \mathrm{C}, 7$ 分とした。次にサンプルを真空デシケー 夕内に 1 時間放置し脱水した後, レジストの解像特性を高 めるために $23^{\circ} \mathrm{C}$ の純水中に 30 分間浸漬した ${ }^{(17)}$ 。露光装置は 図 9 に示すプロキシミティ露光方式のマスクアライナー

（QUINTEL 社製モデル UL-7000）を用い, 露光波長は $350 \mathrm{~nm}$ から 450nm のブロード光，プロキシミティ・ギャップ 1.0 $\mu \mathrm{m}$, コリメーション・アングル $1.5^{\circ}$ とした。露光量は 10.0

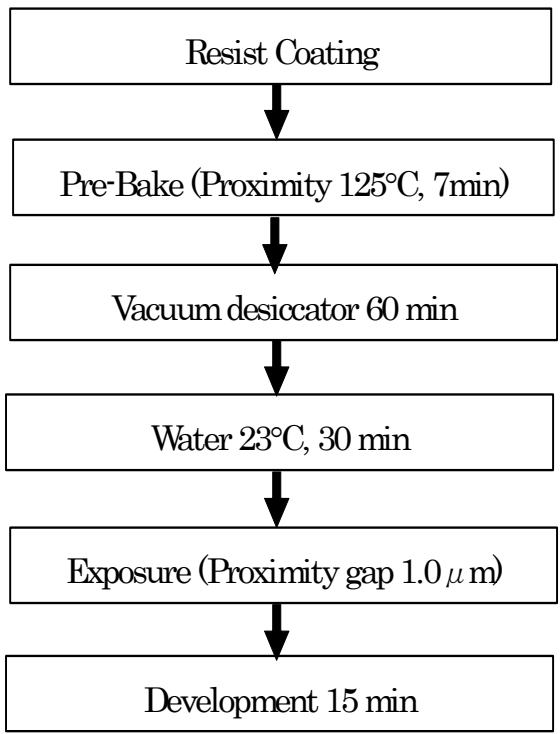

図 8 サンプル作製工程

Fig. 8. Sample preparation process.

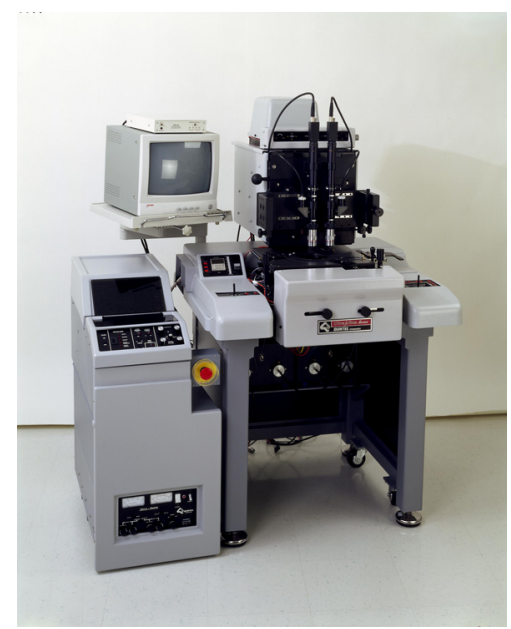

図 9 プロキシミティ露光方式のマスクアライナー

Fig. 9. Maskaligner of proximity exposure mode.

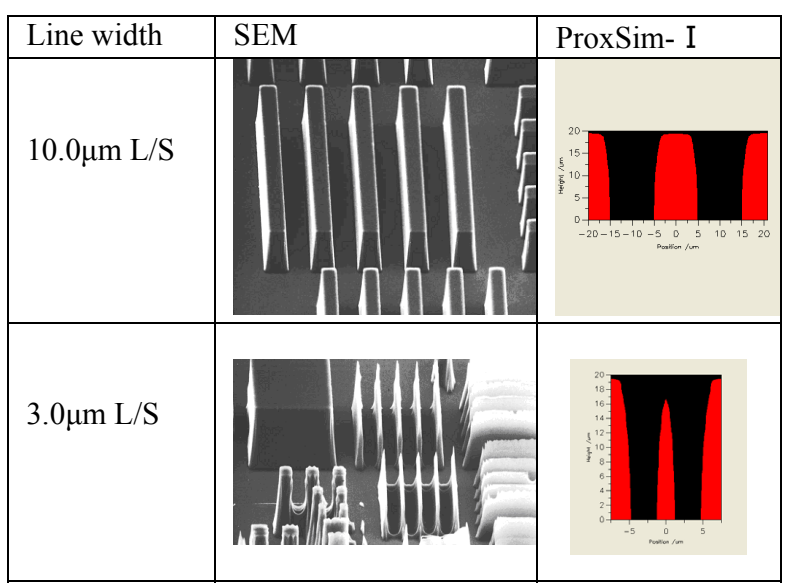

図 10 異なる線幅寸法におけるレジスト形状観察結果 Fig. 10. Resist pattern observation results for the defferent line width. 
$\mu \mathrm{m}$ ラインスペースパターンが 1 対 1 の寸法となる露光量 $E_{o p}$ とした。現像液は厚膜専用の $\mathrm{TMAH}$ 現像液で, $23.0^{\circ} \mathrm{C}$, 15 分間ディップ現像を行った。レジスト膜厚測定時のレジ スト屈折率は 1.68 とした。レジスト線幅寸法は $10.0 \mu \mathrm{m}$ の ラフなパターンと $3.0 \mu \mathrm{m}$ の微細なパターンを用いた。

〈6·2〉 フォトレジスト形状の比較ＳEM 観察および ProxSim- I の計算結果を図 10 に示す。レジスト線幅寸法 $10.0 \mu \mathrm{m}$ では, フォトレジスト形状のトップ部の膜減りが少 なく矩形形状を保っている。レジストパターンの側壁部は テーパーを帯びた形状を呈する。ProxSim- I による計算結果 は SEM 観察とほぼ一致する結果が得られた。しかしフォト レジスト形状の側壁部のテーパー形状についてはフォトレ ジスト膜厚 $10.0 \mu \mathrm{m}$ 付近から基板付近の範囲において再現 できなかった。フォトレジスト線幅寸法 $3.0 \mu \mathrm{m}$ では，フォ トレジスト形状のトップ部の膜減りが発生し尖った形状に なった。フォトレジスト形状の側壁部はテーパーを帯びた 形状を呈する。ProxSim- I による計算結果は SEM 観察とほ ぼ一致する結果が得られた。このことから，実測溶解速度 をProxSim-I に用いることにより現実に近いシミュレーシ ヨン結果が得られることがわかった。

〈6·3〉 現像特性 フォトレジスト形状の解像性の指 標である現像コントラスト ${ }^{(18)}$ (溶解速度曲線の傾き : $\tan \theta$ ) とフォトレジスト感度 $\left(\mathrm{E}_{\mathrm{th}}\right)$ を本溶解速度測定方法にて測 定した結果を図 11 に示す。本溶解速度測定方法にて現像特 性を測定できることを確認した。

\section{〈6・4〉光強度及びレジスト形状シミュレーション}

図 12 にフォトレジスト線幅寸法 $10.0 \mu \mathrm{m}, 3.0 \mu \mathrm{m}, 1.0 \mu \mathrm{m}$ の光強度計算とフォトレジスト形状シミューション結果を 示す。フォトレジスト線幅寸法が微細になるに伴い光強度 が劣化していることがわかる。これは，フォトレジスト線 幅寸法が微細になるに伴い光の回折が大きく発生すること
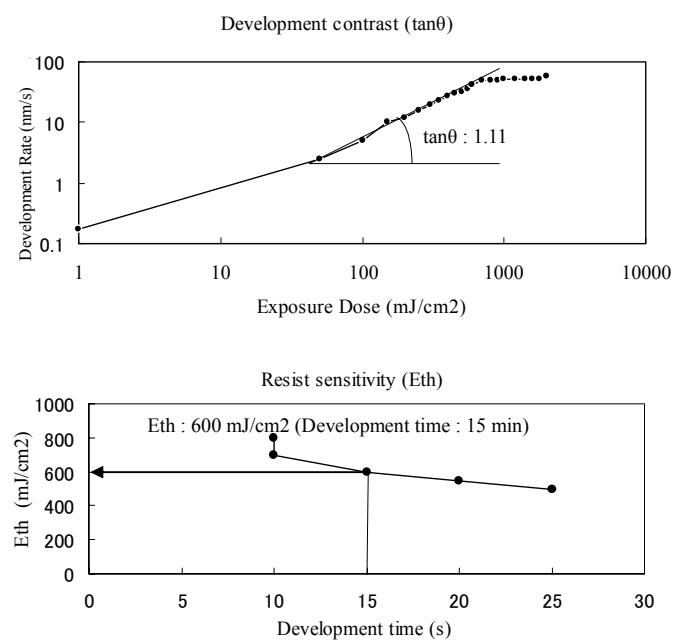

図 11 現像コントラスト $(\tan \theta)$ とレジスト感度 $\left(\mathrm{E}_{\mathrm{th}}\right)$ Fig. 11. Development contrast $(\tan \theta)$ and resist sensitivity $\left(\mathrm{E}_{\mathrm{th}}\right)$.

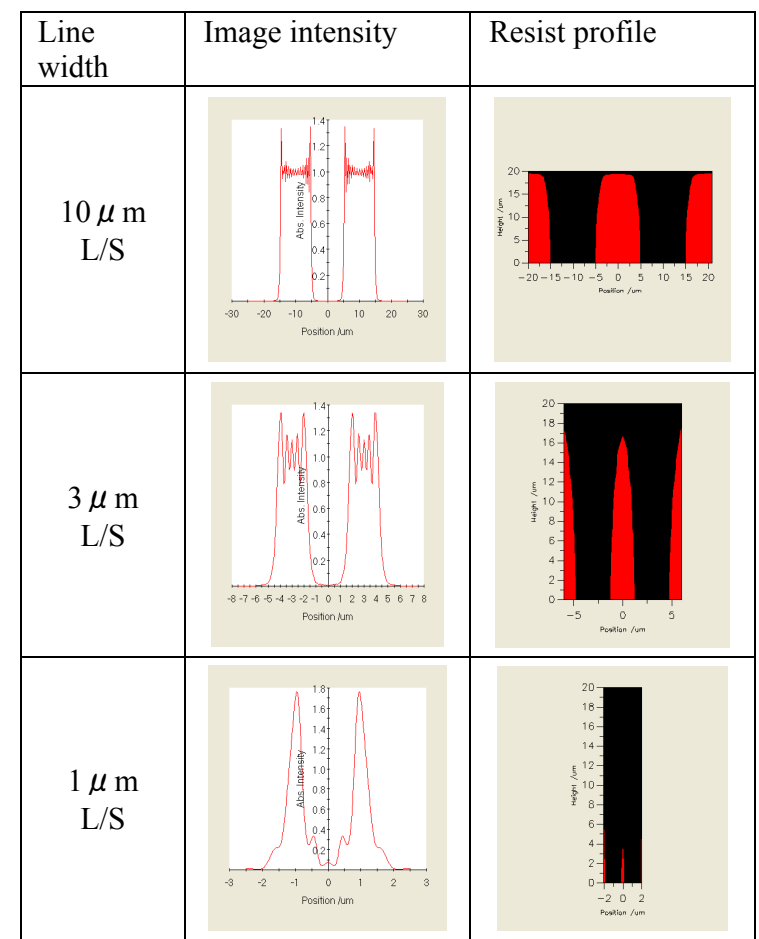

図 12 光強度計算とレジスト形状シミュレーション結果 Fig. 12. Simulation result of image intensity and resist pattern profile.

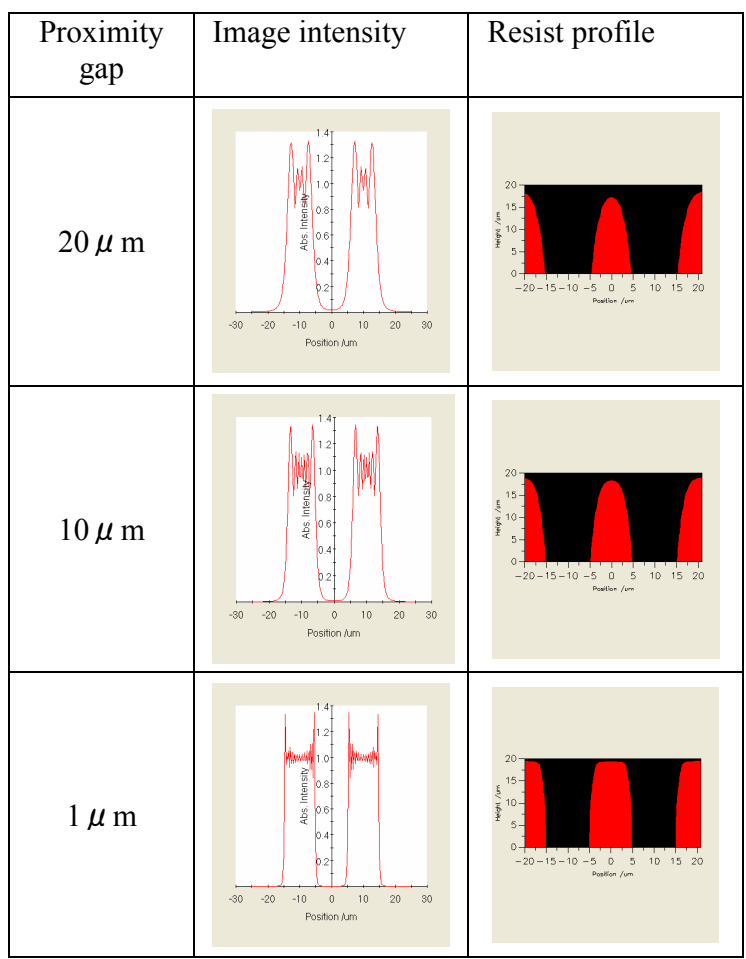

図 13 プロキシミティ・ギャップ值の変化に対する 光強度計算結果

Fig. 13. Simulation result of image intensity for defferent proximity gap. 
に起因していると考えられる。フォトレジスト線幅寸法 1.0 $\mu \mathrm{m}$ において光強度の劣化が著しく, マスクの $\mathrm{Cr}$ (クロム) による遮光部に光が入り込み, マスクの透過部の光が細く なり劣化しており, 解像しないことが確認できる。ProxSim- I によるシミュレーション結果は本現象とほぼ一致してい る。

また, 図 13 にフオトレジスト線幅寸法 $10.0 \mu \mathrm{m}$ における プロキシミティ・ギャップ值（マスクとフォトレジスト間 の距離）を変化させた場合の光強度計算の結果を示す。ギ ヤップ值が大きくなるに伴い光強度が劣化していることが わかる。フォトレジストの膜厚は約 $20 \mu \mathrm{m}$ であることより, プロキシミティ・ギャップ值 $20 \mu \mathrm{m}$ の光強度分布がフォト レジスト膜と基板との境界部分の光強度分布に相当し，こ れはフォトレジスト表面部にあたるプロキシミティ・ギャ ップ $1.0 \mu \mathrm{m}$ の光強度分布に比較し劣化している。従って, SEM 観測とフォトレジスト形状シミュレーション結果の比 較において，テーパー形状が再現できなかった原因は，現 在の ProxSim- I はフォトレジスト膜内方向の光強度の劣化 を考慮していないためであると考えられる。

\section{7. むすび}

厚膜レジストの膜内方向における実測溶解速度とレジス 卜表面位置の光強度分布を組合せることにより，プロキシ ミティ露光におけるレジスト形状シミュレーションを行う ソフトウェア ProxSim- I を開発した。ProxSim- I のシミュ レーション結果はSEM 観測結果とほぼ一致し, 本手法に妥 当性があることを確認した。今後, フォトレジスト膜内方 向における光強度計算を取込む検討とプロキシミティ・ギ ヤップをさらに大きくした場合のシミュレーション結果の 妥当性の検討が必要である。

\section{謝 辞}

ProxSim- I の光強度計算部に関しまして,ソフトウェアの 製作及び御指導いただきました(有)光システム研究所社長の 伊藤徳久氏に感謝いたします。

(平成 15 年 6 月 23 日受付, 平成 15 年 10 月 27 日再受付)

\section{文献}

(1) R. Arai : "Exposure machine for the magnetic head", Electric Parts and Materials, pp.84-89 (2000-2)

(2) Y. Shibayama and M. Saito : "Influence of Water on Photochemical Reaction of Positive-Type Photoresist", J. Appl. Phys., Vol.29, pp.2152-2155 (1990-10)

( 3 ) F. H. Dill, A. R. Neureuther, J. A. Ruttle, and E. J. Walker : "Modeling projection Printing of Positive Photoresists", IEEE Trans. Electron Devices, Vol.ED-22, No.7, pp.456-464 (1975-7)

(4) M. S. Yeung : "Modeling high numerical aperture optical lithography", SPIE, 922, Optical/Laser Micro Lithography, pp.149-167 (1988)

(5) C. A. Mack : "PROLITH : a comprehensive optical lithography model", SPIE, 538, pp.207-219 (1985)

(6) D. A. Bernard : "Simulation of Focus Effects in Photolithography", IEEE Trans. Semiconductor Manufacturing, Vol.1, No.3, pp.85-97 (1988-8)
( 7 ) W. Henke and G. Czech : SIMULATION OF LITHOGRAPHIC IMAGES AND RESIST PROFILES, pp.629-633, Elsevier Science Publishers B. V. (1990-11)

(8) C. M. Garza and S. O. Grindle : "Resist Characterization and Optimization Using A Development Simulation Computer Program. PROSIM", SPIE, 631, Advances in Resist Technology and Processing III (1986)

(9) T. Batchelder and J. Piatt:「ポジ型フォトレジストのベーキング効果」, Solid State Technology 日本版, pp. 55-61 (1984-2)

(10) 遠藤政孝・笹子 勝・上野 厚・野村 登:「新規高解像レジストプ 口セス」, 第 35 回応物春季予稿集, 2, 28 p-H-7, p.509 (1988)

(11) P. H. van Cittert : "Die wahrscheinliche Schwingungsverteilung in einer von einer Lichtquelle direct oder mittels einer Linse beleuchteten Ebene", Physica, Vol.1, pp.201-210 (1934)

(12) F. Zernike : "The Concept of Its Application to Optical Problems", Physics, Vol.5, pp.785-795 (1938)

(13) H. H. Hopkins : "On the diffraction theory of optical image", Pro. Roy. Soc., A217, pp.408-432 (1953)

(14) D. Adalsteinsson and J. A. Sethian : "A Level Set Approachtoa Unified Model for Etching, Deposition, and Lithography I : Algorithms and Two-Dimensional Simulations", J. Computat. Phys., Vol.120, pp.128-144 (1995)

(15) Y. Hirai, S. Tomida, K. Ikeda, M. Sasago, M. Endo, S. Hayama, and N. Nomura : "Three-Dimensional Resist Process Simulator PEACE", IEEE Trans. Comput. Aided Des., Vol.10, No.6. pp.802-807 (1991-6)

(16) Y. Sensu and A. Sekiguchi : "Improved resolution of thick film resist", SPIE, 4979, pp.561-581 (2003-1)

(17) Y. Sensu, Y. Miyake, and A. Sekiguchi : "Study on Improved Resolution of Thick Film Resist”, IEICE Trans. (C), Vol.J85-C, No.4, pp.260-268 (2002-4) (in Japanese)

扇子義久・三宅康宏・関口 淳: 「厚膜レジストの高解像化に関する 検討」，信学論(C), J85-C, 4, pp.260-268 (2002-4)

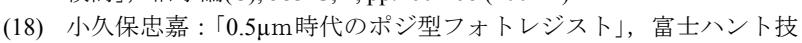
術セミナー‘88, p.6(1988)

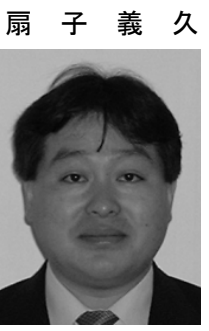

（非会員） 1985 年住友 GCA に入社。自動終点 検出装置の開発に従事。その後, レジスト解析 装置および形状シミュレータのシステム開発に 従事。1994 年リソテックジャパンに入社。現在 に至る。応用物理学会会員。

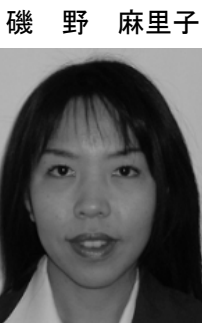

（非会員）1997 年埼玉工業大学卒業。同年リソ テックジャパンに入社。同社にてフォトレジス 卜の特性解析ソフトウエアの開発に従事。応用 物理学会会員。

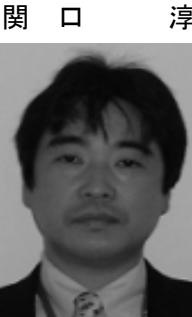

（正員） 1982 年芝浦工業大学卒業。1983 年日 本ケミテック入社。無電解 $\mathrm{Au}$ メッキ試薬の開 発に従事。1985 年住友 GCA 社に入社。レジス 卜塗布現像装置のプロセス開発に従事。その後, レジスト解析装置および形状シミュレータのシ ステム開発に従事。現在, リソテックジャパン 取締役。工学博士。応用物理学会会員。電子情 報通信学会会員。 


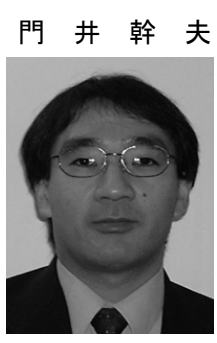

（非会員） 1988 年 3 月東北大学修士課程卒業。 同年三菱金属（現三菱マテリアル）に入社。同 社中央研究所で主にシリコン単結晶育成技術お よび欠陥解析技術の開発に従事。1990 年三菱マ テリアルシリコンに出向。1995 年リソテックジ ヤパンに入社。現在に至る。応用物理学会会員。

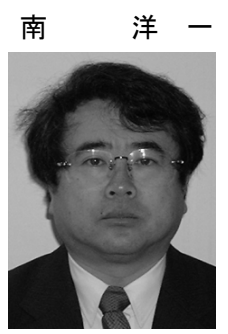

（非会員） 1979 年東京電機大学卒業。同年プロ セスシステム入社。米国 GCA 社のフィールドサ ービスに従事。1983 年住友 GCA 社に入社。コ ータデベロッパの国産化に従事。その後, 現像 終点検出コントロール装置の開発に従事。以来 それらを応用したレジストプロセス解析装置の 開発に従事。現在リソテックジャパン代表取締 役。応用物理学会会員。

松 澤 敏 晴 （非会員）1975 年東北大学修士課程卒業。同年

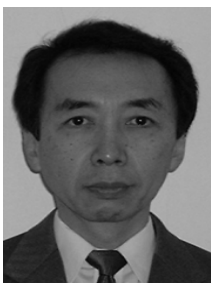
日立製作所に入社。同社中央研究所で主にフォ トリソグラフィのプロセス技術およびシミュレ ーション技術の開発を行う。1988 年テクノフロ ント設立。1993 年リソテックジャパン設立に参 加, 両社を兼務し, 現在リソテックジャパン取 締役。工学博士。応用物理学会会員。IEEE 各会 員。 